\title{
CCND1 Protein Overexpression
}

National Cancer Institute

\section{Source}

National Cancer Institute. CCND1 Protein Overexpression. NCI Thesaurus. Code C36485.

A molecular abnormality indicating the presence of an abnormally high level of the G1/Sspecific cyclin-D1 protein. 